\title{
Flow and internal structure of a rock glacier
}

\author{
Roger F. Elconin, ${ }^{1 *}$ Edward R. LaChapelle ${ }^{2}$ \\ ${ }^{1}$ P.O. Box 202872 Anchorage, Alaska 99.520, U.S.A. \\ ${ }^{2}$ Department of Atmospheric Sciences and Geophysics Program, University of Washington, Seattle, Washington 98195, U.S.A.
}

\begin{abstract}
Exposure of a full transverse cross-section of the terminus of Fireweed rock glacier, Wrangell Mountains, Alaska, revealed a thin layer of unconsolidated debris mantling a consolidated mélange of ice and rock. The main rock glacier is fed by three tributaries; at the terminus, contacts between the three are sharply defined. Ice content is $>50 \%$ by volume. Bubble foliation and crystal morphologies of the ice matrix are similar to those reported from glacier ice. Folded ice-rich strata and lenses, foliation planes, and the long-intermediate axial planes of tabular-shaped englacial clasts dip steeply toward the center line of the rock glacier. The planar structures generally parallel the steep walls of the gorge containing the trunk stream. These steeply dipping, longitudinal structures appear to result from transverse compression where the tributaries converge and the trunk stream narrows down-valley.

Bergschrund-like and moulin-like features at the heads of the middle and west tributaries, respectively, exposed admixed ice and rock similar to that of the terminus but lacking the well-developed flow texture. Talus from the unstable cirque headwall and polygenetic ice both accumulate at the base of the headwall and nourish the tributary rock glaciers.
\end{abstract}

\section{INTRODUCTION}

Rock glaciers, by their nature, do not readily lend themselves to internal inspection. Our understanding of internal composition and structures of rock glaciers, and thus their genesis, is based largely on speculation. Most information on internal composition comes from shallow outcrops, geophysical surveys and geomorphology. Apparently only two large exposures of the internal structure of rock glaciers have been photographed and described (Fisch and others, 1978; Moore and Friedman, 1991). Observations at depth have also been made in a tunnel in Hurricane Basin rock glacier (Brown, 1925), and on cores retrieved from boreholes in rock glaciers (Barsch, 1977; Barsch and others, 1979; Johnson and Nickling, 1979; Haeberli and others, 1988; Hamre and McCarty, 1996). Numerous observations, both shallow and deep, have variously identified massive ice, debris-laden ice, and ice-free detritus.

A number of rock glaciers exist on the southern flank of the Wrangell Mountains in south-central Alaska, U.S.A. They were studied in the vicinity of the historical Kennecott Copper Mine (Fig. 1) in 1909 by Capps (1910). Many shallow excavations into several of these rock glaciers revealed the following: "in every instance clear ice was found; not massive ice, however, but interstitial ice, filling the cavities between the angular fragments and forming, with the rock, a breccia with the ice as a matrix" (p. 362).

The hallmark of the Kennecott Copper Mine was highgrade chalcocite ore, and during the same era as Capps' study a small rock glacier that contained ore was extensively

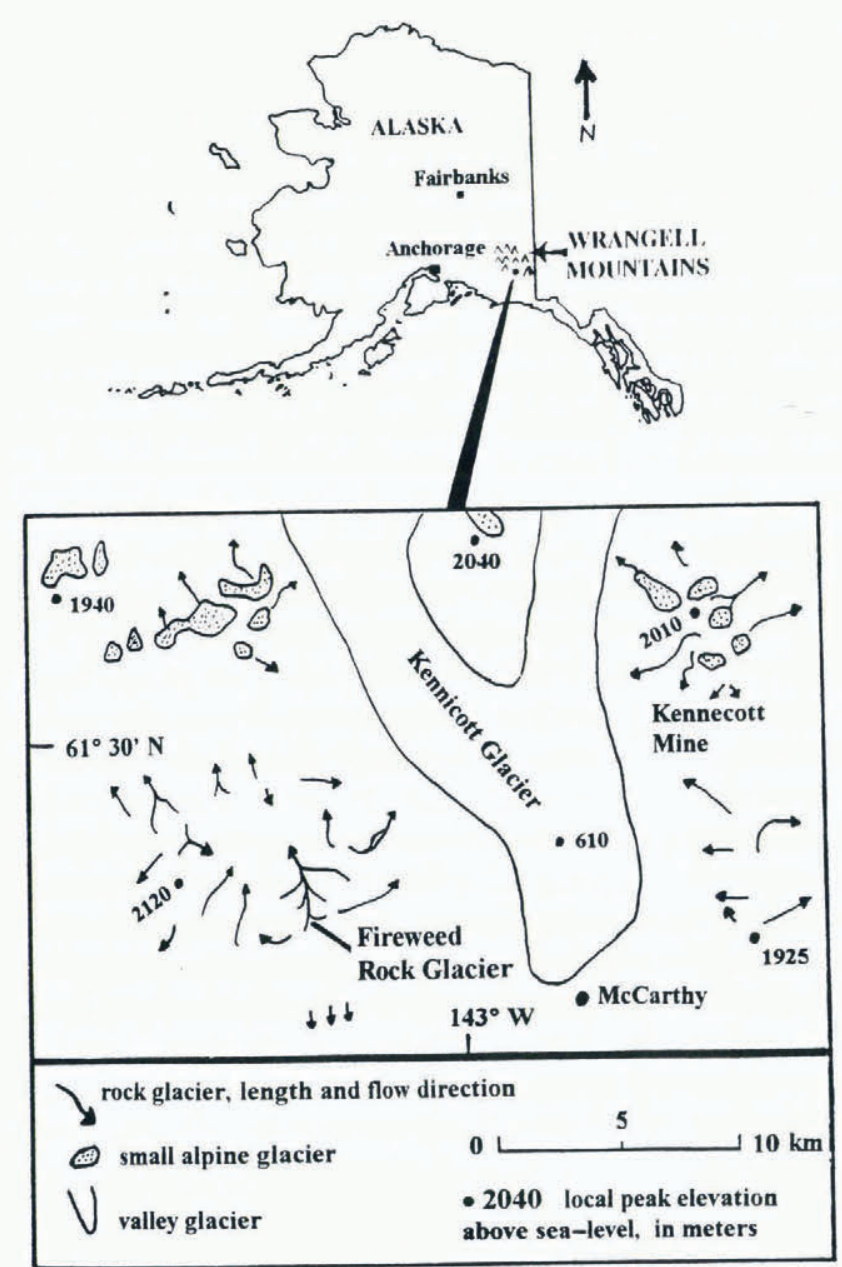

* Formerly at Department of Geology, Humboldt State University, Arcata, California 95521, U.S.A. 
mined. Bateman and McLaughlin (1920, p. 23-24) describe the workings and what was found: "An ice glacier seems an impossible 'country rock' for an ore body, yet such is the case... The debris accumulation and the building up of the glacier went on hand in hand during the Glacial period, for now the ore occurs deep within the glacier. The glacier with a steeply sloping front has been explored by means of three tunnel levels from which several cross cuts have been run, enabling the ore body to be partially outlined and sampled... Perhaps 30 to 60 per cent of the material within the ore body is accumulated debris, the remainder being ice."

In late summer 1993 a moderate flood occurred in the streams on the southern flank of the Wrangell Mountains. A swollen stream issuing from beneath the crevassed snout of an active and well-developed rock glacier caused the snout to calve, exposing a full transverse cross-section of an ice-rock mélange. Detailed on-site investigation of the exposed face began on 5 June 1994 and ended with the first alpine snowfall on 1 September. The site was revisited briefly in September 1995, but by then the face was completely buried by slumped debris. The various compositions and structures exposed in the face were documented and roughly mapped. Other fieldwork included geomorphologic studies of the entire rock glacier and adjacent environs. The following is a description of the internal composition and structure gleaned from this unique exposure, and the insight gained regarding this rock glacier's rheology and genesis.

\section{LOCAL SETTING AND GENERAL DESCRIPTION OF THE ROCK GLACIER}

The climate of the study region is influenced by maritime and interior air masses which support numerous alpine and valley glaciers. Mean annual air temperature, measured over the last 27 years at stations near the rock glacier but lower in clevation (396 and $457 \mathrm{~m}$ ), is $-2^{\circ} \mathrm{C}$. No data are available for mean annual ground temperature, but periglacial environs contain discontinuous permafrost.

The rock glacier discussed here, which we have informally named Fireweed rock glacier $\left(61^{\circ} 27^{\prime} \mathrm{N}, 143^{\circ} 05^{\prime} \mathrm{W}\right)$, is situated in a northerly-facing compound cirque (Fig. 2). This cirque system hosts six major talus and ice-alimentation sites from which six rock glaciers emanate. The three largest and best developed of these coalesce to form a single trunk rock glacier (Fig. 3). Henceforth, the three tributaries are referred to as the east, middle and west tributaries. They are $50-125 \mathrm{~m}$ wide in their tributary portions, but the widths decrease below the confluence. The east tributary is over $2000 \mathrm{~m}$ long and is composed chiefly of light- to darkgray hypabyssal (igneous) rock. The middle tributary contains both the hypabyssal rock and a reddish, thermally altered mudstone. It is approximately $1720 \mathrm{~m}$ long. The $2100 \mathrm{~m}$ long west tributary is largely composed of the altered mudstone, giving it a diagnostic reddish color. The tributaries originate at elevations of $1430-1500 \mathrm{~m}$ and have average slopes of $14-17^{\circ}$. The elevation at the terminus is approximately $970 \mathrm{~m}$. The surface expression of the three tributaries is longitudinally continuous from head to terminus. The maximum flow rate of the trunk rock glacier, measured from 1994 to 1996 at a point $125 \mathrm{~m}$ from the terminus, exceeded 3.80 m year $^{-1}$.

The three tributaries exhibit features listed below that are also common to active rock glaciers in the region:

ice-cemented detritus and massive ice covered by a thin unconsolidated debris mantle;

firn and talus fields at the heads of the rock glaciers, with

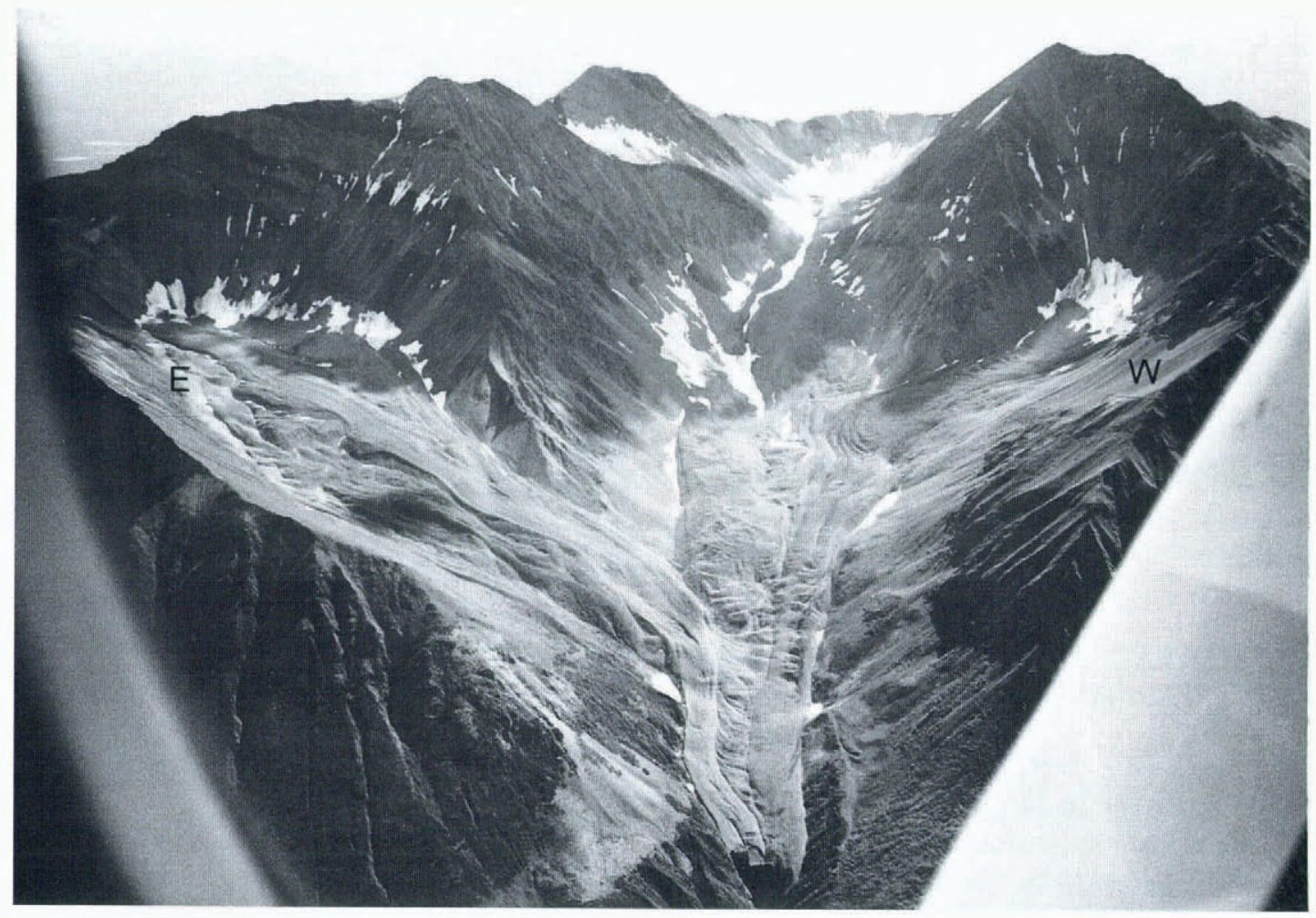

Fig. 2. Looking south at the north-facing compound cirque and rock-glacier system on Fireweed Mountain at maximum snowline retreal. Firn fields on lower parts of cirque headwalls mark the "accumulation zone" and head of each tributary rock glacier. The tributaries at the far left and far right comprise the east and west tributaries, respectively. Distance across the terminus is approximately $100 \mathrm{~m}$. 


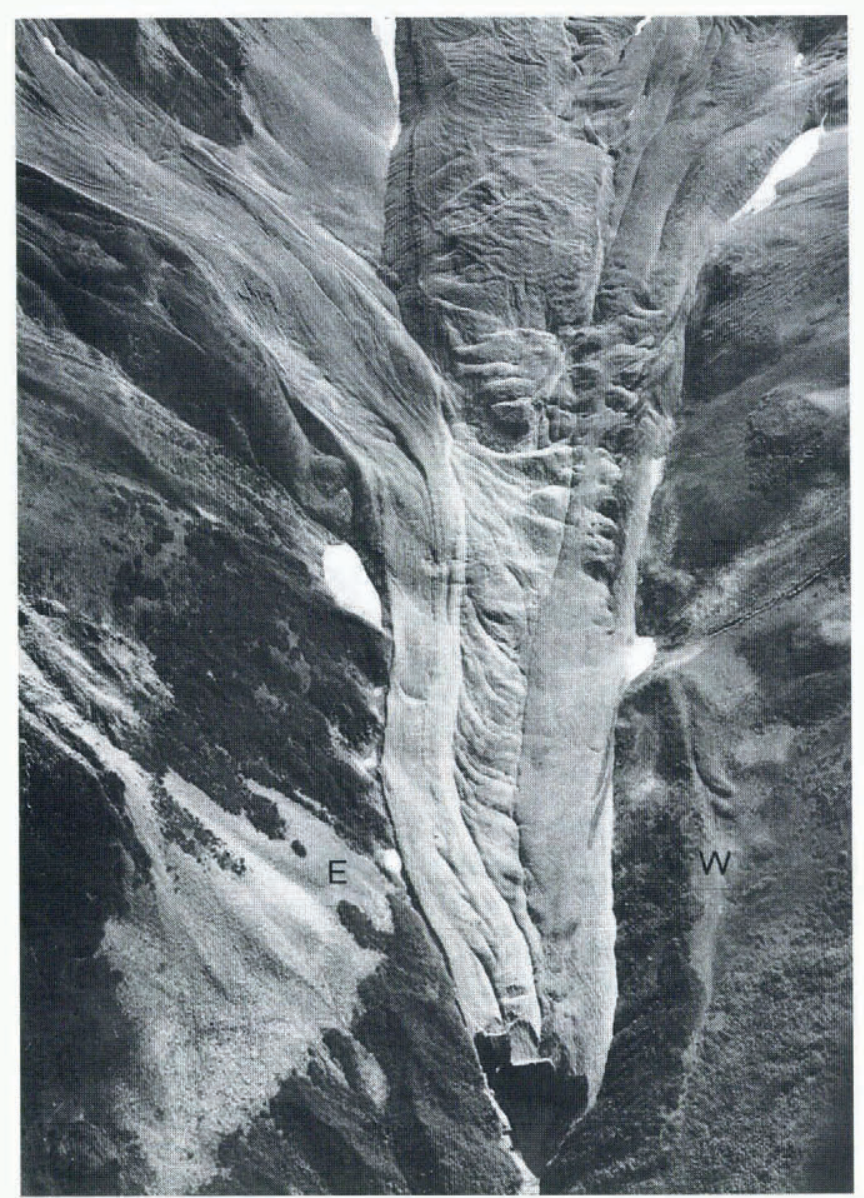

Fig. 3. Rock-glacier trunk stream composed of the east, middle, and west tributary rock glaciers. Distance across the terminus is approximately $100 \mathrm{~m}$.

vigorous talus production and snow avalanche activity above the rock-glacier heads;

rounded to flat-top longitudinal ridges with intervening $\mathrm{V}$-shaped furrows;

rounded transverse ridges and furrows;

seasonally audible subsurface running water in parts of the longitudinal furrows;

large pits and linear depressions;

oversteepened lateral flanks and flow fronts with slopes of generally $32-46^{\circ}$;

small- to large-scale fresh surface disturbances consistent with downslope flow (Elconin, 1992); and

lichen and moss, low-relief vascular plants, and a few scrubby spruce, willow and alder mostly on lower reaches.

\section{ADVANGE, RETREAT AND BURIAL OF THE ROCK-GLACIER TERMINUS}

The terminus of Fireweed rock glacier retreated more than $50 \mathrm{~m}$ from 1 September 1993 to 15 October 1994, leaving a sharply defined trim line on the walls of the gorge. Scrub alder (Alnus sitkatensis) exposed by the retreat were rooted, dead, hardly decomposed, and of comparable size to living alder above the trim line, indicating that the rock glacier had recently advanced into the gorge. The retreat began during or shortly before the late-August 1993 flood and was characterized by crevassing of the terminus and calving of small to large blocks of rock-glacial material into the gorge. Also, ablation of the exposed face by melt was significant. Englacial and mantle rock debris that fell from the face was effectively removed by the swollen stream that issued from beneath the face.

By early October 1993, water discharge from beneath the snout had decreased enough to allow accumulation of fallen rock debris. By mid-June 1994, the lower one-third of the face had become buried. A marked spring freshet in the middle of June 1994 issued from beneath the snout and catastrophically removed the accumulated debris, promoting further calving of the frozen core and increasing delivery of rock debris into the gorge. Within 3 weeks, the discharge decreased and the stream established a stable course through fallen debris. Hydraulic removal of the debris ceased once again, allowing burial of the face to resume. As noted above, the face was completely buried by September 1995.

\section{INTERNAL COMPOSITION AND STRUCTURE OF THE TERMINUS}

\section{Character of the exposed face}

Figure 4 shows the exposed face of the rock-glacier terminus as it appeared in late July 1994. The face was, for the most

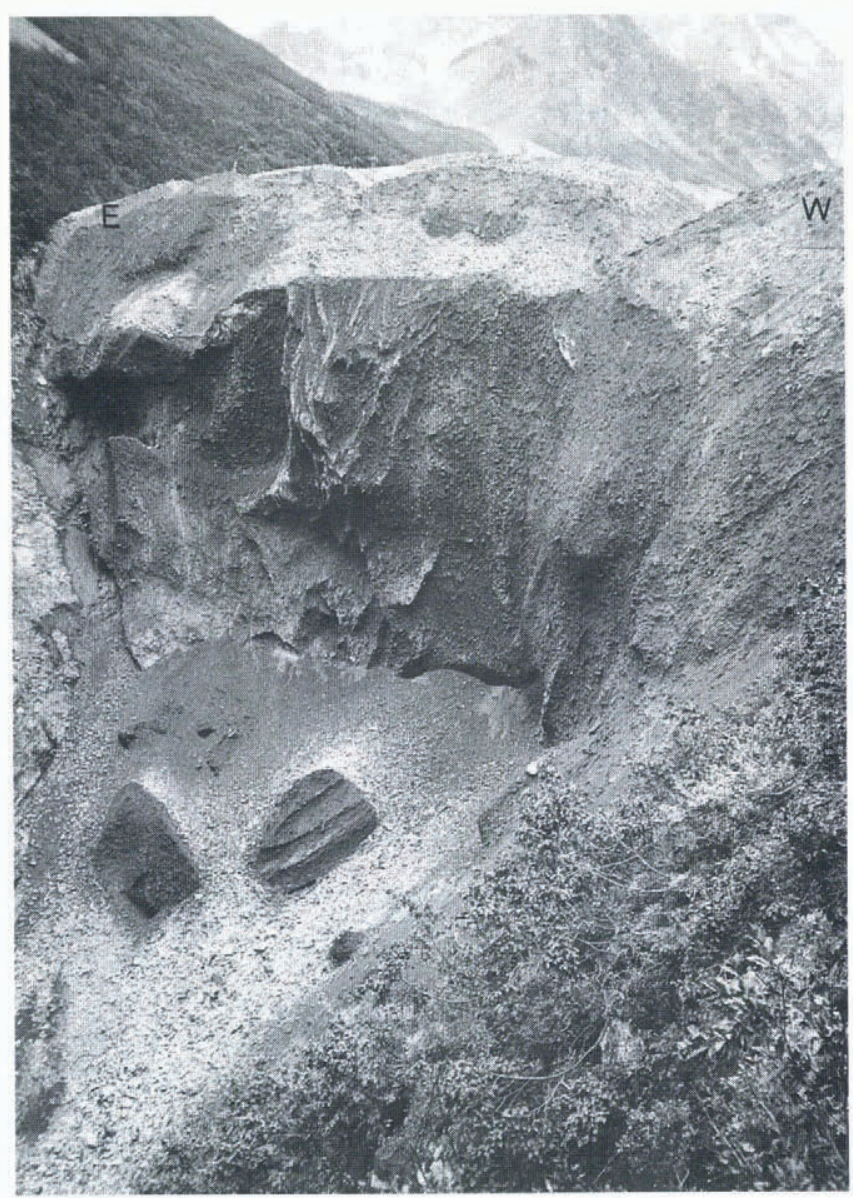

Fig. 4. Overview of the arcuate vertical face in mid-fuly 1994. Distance across the top of the face is approximately $90 \mathrm{~m}$. The lower half of the face is covered by ablation debris from within and above the face. Two calved blocks from the rock glacier's frozen core are lying on the debris apron. The one on the right fell from the tightly folded domain of the east tributary directly above; note the folded structure in this block. 
part, nearly vertical. The distance across the top of the face was over $90 \mathrm{~m}$, and distance from the top of the face to the gorge bottom was approximately $60 \mathrm{~m}$. The maximum cross-sectional area of the exposed face was roughly $3000 \mathrm{~m}^{2}$. Debris on the rock-glacier surface covered a consolidated ice-rock mass filling the bedrock gorge. There was an internal vertical grain to the exposure, defined by ice-rich strata and lenses, and by contacts between flows.

\section{Tributaries identified in the face}

In the vertical face, there are sharp contacts between material from the three tributaries. The tributaries are differentiated by color, englacial clast quantity and size, and geomorphology. The east tributary is light to dark gray. The west tributary is reddish. The middle tributary, attenuated at the terminus, appeared in the face as a thin, vertically oriented domain. It is redder than the west tributary, and contains larger and more abundant clasts relative to the west and east tributaries. The contacts between the tributaries are delineated on the surface of the rock glacier by two continuous longitudinal furrows that extend along the length of the trunk rock glacier (Fig. 3).

A prominent domain within the east tributary is composed of isoclinally folded ice-rich and debris-rich strata with a longitudinal strike. This inset domain is delineated on the surface of the rock glacier by the longitudinal furrow between the middle and east tributaries and by a discontinuous longitudinal furrow that equally divides the lower $100 \mathrm{~m}$ of the east tributary (Fig. 3). The western half of the east tributary consists of this tightly folded structure. A smaller inset debris-rich domain exists on the east side of this larger folded structure.

\section{An ice and rock mélange}

Figure 5 is a close-up of the east tributary, and is illustrative of most of the face. The core is a chaotic mixture of rock fragments of all sizes in a deformed matrix, or a "mélange" (Bates and Jackson, 1987). Clasts are generally less than $0.5 \mathrm{~m}$ in diameter and occur with the deformed ice as: (1) essentially debris-free to lightly littered ice layers, lenses and pods, with intervening and surrounding debris-rich ice of varying rock -ice percentages, and (2) debris-rich stringers, lenses and pockets of irregular size and occurrence with varying amounts of interstitial ice. We estimate that total ice content is greater than $50 \%$ by volume. With few exceptions, clasts are ice-supported, although only a few millimeters may separate adjacent clasts.

Ice laden with silt and clay is abundant. This dirty ice in the east tributary is tan in color and exists as steeply dipping and longitudinally striking lenses and thin streaks, or as unstructured forms within large clean-ice pods. Ice laden with silt and clay in the west tributary is reddish in color, appears to be more abundant than in the east tributary, and occurs mostly in unstructured form. Ice laden with silt and clay may originate at the heads of the tributary rock glaciers, where fine-grained material becomes incorporated in firn and ice (Fig. 6).

\section{Englacial clast fabric}

Tabular-shaped clasts are abundant and have a strong preferred orientation. The plane defined by the long and intermediate axes dips steeply and strikes longitudinally, parallel

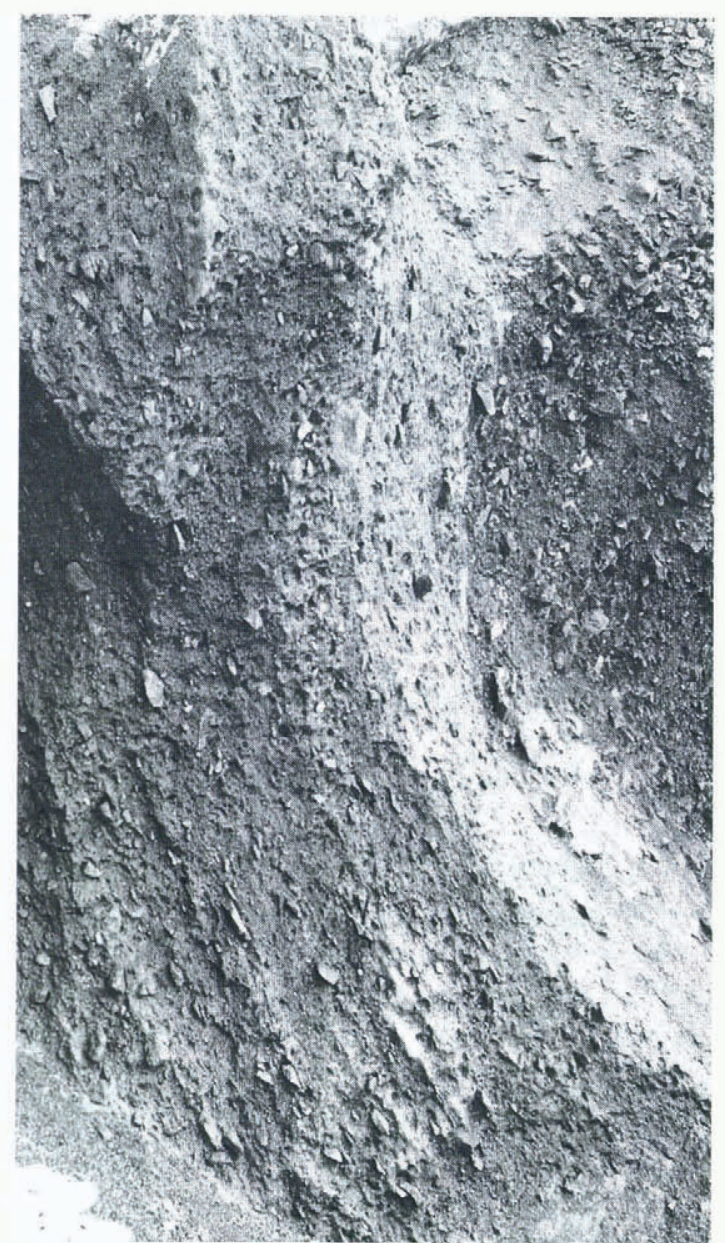

Fig. 5. This part of the east tributary is representative of the ice rock mélange that exists throughout most of the exposed face. Debris concentrations may appear higher than they actually are, due to the combined effect of a thin muddy slurry that veiled parts of the face and the opaque nature of debris-laden ice. Note the steeply dipping fabric of tabular-shaped clasts. Distance from top to bottom of photo is approximately $10 \mathrm{~m}$.

to flow. Strong clast orientation is most prevalent in the east tributary, probably because it contains more tabular clasts. Prolate clasts are also oriented with their long axes generally parallel to flow.

\section{Foliated ice}

Foliated ice is one of the signatures of the deformed ice matrix. The foliation is defined by variations in bubble and dirt content or by alternating and discontinuous frosty and dark ice bands. The plane of foliation dips steeply and is parallel to flow. At the terminus, the plane of foliation parallels the long-intermediate axial plane of the preferentially oriented tabular-shaped clasts. The dark bands, 1-20 mm thick, are mostly devoid of air bubbles. The frosted bands are rich in bubbles that are approximately $1 \mathrm{~mm}$ in diameter and up to $20 \mathrm{~mm}$ in length. The elongation is in the plane of foliation and parallel to the longitudinal axis of the rock glacier. Spherical bubbles, 1-2 mm in diameter, are present but less abundant. Intensely foliated ice was observed in association with debris-laden ice and not in association with debris-poor massive ice bodies.

Characteristics of the foliated ice varied in adjacent sites. A closely inspected portion of the east tributary showed laminae that are mostly planar. The frosted and dark bands 


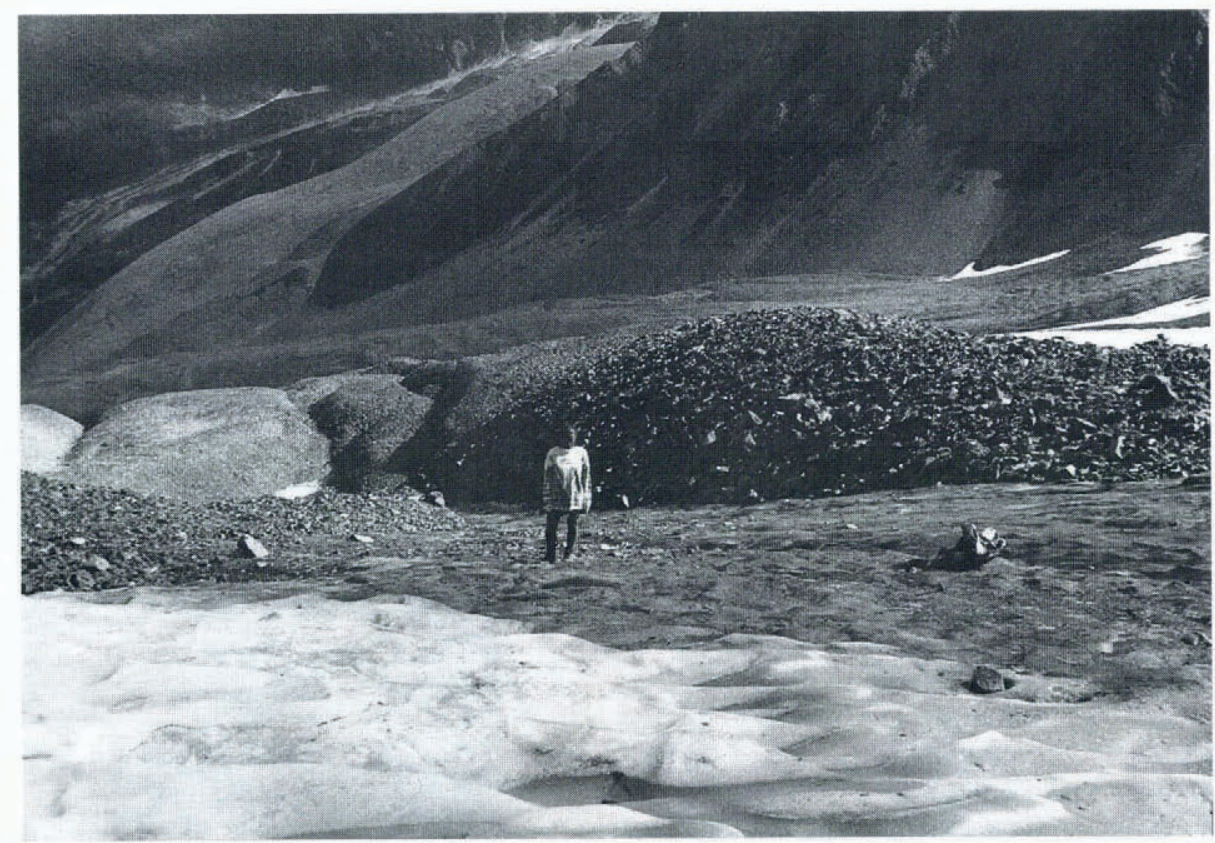

Fig. 6. Photo looking downstream on the west tributary, taken at the head or "accumulation zone" at maximum snowline retreat. The large and small talus piles to the left and right of the person are illustrative of talus accumulations at the heads of the rock glaciers described herein. These talus accumulations are generally thought to become ice-cemented after deposition; they are thus periglacial in origin. However, the dirty and clean firn and ice in the foreground accumulates in a manner more akin to glacial or sedimentary processes. The person is standing on firn and ice laden with fine-grained weathered rock and organic matter. This dirty firn and ice is thought to be the protolith for the silt-and clay-laden ice identified at the terminus.

are roughly equal in occurrence, although the dark bands are thinner. At a nearby site in the east tributary the laminae are gently folded, and the darkened bubble-free ice is more abundant and relatively irregular in occurrence. Samples extracted from the west tributary showed alternating and discontinuous bands of bubbly dirty ice and clean ice with fairly consistent thicknesses of 5-10 mm. These laminae were planar to intensely folded. They were bent in a streamlined fashion around fist-sized clasts or dense clusters of small clasts.

\section{Character of the isoclinally folded ice-rich domain}

The folded ice-rich domain of the western half of the east tributary is the only relatively highly ordered, large-scale structure identified in the face (Fig. 4). It is comprised of isoclinally folded strata of debris-poor and debris-rich ice. There is an approximately $2.5 \mathrm{~m}$ thick debris-rich vertical layer in the middle of the feature that is oriented parallel to flow. The folded structures are mirrored about this vertical layer, suggesting that it represents the axial plane of an isoclinal fold. The axial plane and strata are highlighted by differential melt; the debris-laden ice ablates faster.

The cleanest and most abundant ice in the face exists in the ice-rich strata of this unique feature. Ice-layer thicknesses range from a few decimeters to a few meters, and consist primarily of debris-free ice, patchy silt and clay-laden ice, widely spaced bands, $<50 \mathrm{~mm}$ thick, of pebbly debris, and randomly occurring boulder-size clasts. Elongated air bubbles in the debris-free ice were ubiquitous in a closely inspected outcrop, and were elongated parallel to the planar pebbly bands. Ice from this feature, inspected in thin section under crossed polaroids, revealed crystal morphologies similar to those reported from glaciers. Extracted samples exposed to the sun developed etched boundaries of interlocking crystals of roughly $10-30 \mathrm{~mm}$ average size.

\section{INTERPRETATION OF FOLIATION, GLAST ORIENTATION, AND FOLDING}

\section{General statement}

Foliation, defined by variations in concentration of elongate bubbles, in Fireweed rock glacier is similar to that reported in numerous other glacier studies (e.g. Allen and others, 1960; Gunn, 1964; Rutter, 1965; Hambrey, 1976). These studies document such foliation in glaciers dominated by longitudinal flow with a component of transverse compression, although similar foliation also occurs in deeper parts of ice caps and ice sheets (Hooke and Hudleston, 1980). Such foliation is created by flow through a steep-walled valley, around a promontory, or by the confluence of tributary glaciers. The similarity between these glacier channel environments and that of Fireweed rock glacier are striking. This analogy affords a first approximation of the stress field in the trunk stream. The tributary rock glaciers join $520 \mathrm{~m}$ upstream from the terminus, forming a confined trunk stream within a down-valley narrowing gorge.

\section{Foliation and flow}

There is general agreement in the literature that ice foliation develops principally by deformation of various primary inhomogeneities under conditions leading to high compressive strains augmented by high shear strains (works cited above, augmented and summarized by Hooke and Hudleston (1978), Hambrey (1979) and others). In the case of foliation in glaciers, these inhomogeneities include stratified ice, irregular assemblages of ice with varying fabrics, and englacial debris of varying origin, content and size. Similarly, foliation in Fireweed rock glacier appears to form by glacier-like flow of debris-laden polygenetic ice in an environment promoting high strains. 


\section{Clast fabric and flow}

Glacier ice deformed in shear systematically reorients englacial debris as well as produces flow signatures such as foliation. The preferred orientation of long axes of englacial clasts parallel to flow has been documented in various glacial environments (e.g. Holmes, 1941; Boulton, 1970; Lawson, 1979; Sharp, 1982; Ham and Mickelson, 1994). These field observations, as well as experimental and theoretical work (e.g. Jeffery, 1922; Manley and others, 1955; Glen and others, 1957), suggest that the long axes of suspended particles in a flowing viscous fluid, and in glacier ice, will predominantly be oriented parallel to flow.

\section{Folding, foliation and flow}

In glaciers, parallel alignment of foliation and the axial planes of folds results from flow in a laterally shortening strain environment (e.g. Matthews and others, 1971; Hambrey, 1977). By analogy, this may explain the general parallelism of foliation and the axial plane of the tightly folded structure in the east tributary of the rock glacier. Field observations in glaciers have revealed how such folding can develop, and the associated strain history of the process (McCall, 1952; Hambrey, 1975; Hambrey and Müller, 1978; Hooke and Hudleston, 1978). Gomez and Small (1985) describe steeply dipping, longitudinally striking debris-rich bands in a small compound glacier in Switzerland. The debris bands were originally formed in the accumulation zone by burial beneath annual snow layers. Subsequent down-glacier flow thins the layers and deforms them so that they parallel the direction of glacier flow. Transverse compressive strains within the ice, due to flow around promontories or convergent flow, reorient and enhance the dip of the strata. In Fireweed rock glacier, steeply dipping ice-rich strata observed throughout the terminus, including the tightly folded structure in the east tributary, probably formed in a similar fashion.

\section{Conclusion}

The internal structure of Fireweed rock glacier is similar to that of more typical temperate glaciers with lower debris contents. Both involve near-melting ice containing rock debris and subjected to large finite strains. A study of the basal region of a sub-polar glacier via a tunnel led Echelmeyer and Wang (1987) to a similar conclusion; the composition, structure and deformation of ice with dispersed rock debris and ice-cemented drift that they found are comparable to those found in rock glaciers and in creeping permafrost.

\section{ALIMENTARY PROGESSES AND ROGK GLAGIER GENESIS}

The steady accumulation of polygenetic ice and talus at the heads of the rock glaciers nourishes the tributaries. Processes accounting for the accumulation of the ice and talus are divided into two general categories: (1) those that are sedimentary or glacial in origin, and (2) those that are periglacial in origin. Neither process excludes the other, and both exist in close proximity in space and time. We do not presently know if one of the two alimentary processes is dominant.

The head of each branch of Fireweed rock glacier is nested in the lower part of the headwall of a cirque (Fig. 2).
The uppermost limits of the tributaries are marked by a break in slope some tens of meters from the base of the steep headwalls, and are natural zones of accumulation by avalanche and snowfall. Accumulations of snow, firn and ice are relatively well preserved in these areas as they are shaded by lofty north-facing cirque walls. These sites are also accumulation zones for rockfall material shed from the cirque walls. Sufficient supply and subsequent metamorphism of the snow proceeds hand in hand with the addition of talus, and gives rise to a mass of ice and rock of sedimentary origin (processes well documented in alpineglacier and rock-glacier studies, e.g. Potter, 1972; Reheis, 1975; Gomez and Small, 1985; Rogerson and others, 1986).

A significant proportion of the talus in the accumulation zones studied arrives by small-scale episodic debris avalanches and fluidized flows, and takes the form of ice-poor talus piles, tongues, fields and pro-talus ramparts. The voids within the talus fill with ice, or expand with excess ice. This ice can originate from the refreezing of melted snow and ice, and freezing of water from meteoric and spring sources. Interstitial and massive ice can also form by migration and freezing of water under thermodynamic potentials and hydrostatic pressure gradients. These processes give rise to in situ ice growth of periglacial origin (e.g. Wahrhaftig and Cox, 1959; Wayne, 1981; Haeberli, 1985; Haeberli and Vonder Mühll, 1996).

Stratigraphy exposed at the heads of the middle and west tributaries demonstrates this bimodal process of ice and rock accumulation. A bergschrund-like feature in the accumulation zone of the middle tributary exposed stratigraphy of predominantly sedimentary origin. Underlying a discontinuous, thin surface talus cover was a $3-5 \mathrm{~m}$ thick layer of mostly clean firn with a few sub-horizontal ice lenses. Beneath this was a 1-2 $\mathrm{m}$ thick layer of debris-laden ice, which was underlain by a few meters of mostly debrisfree ice.

Conversely, immediately below the accumulation zone of the west tributary, a moulin-like feature had cut through ice-cemented detritus. No massive ice or discernible fabric of the densely arranged detritus was observed in the walls of the shaft. The accumulation zone of this tributary, shown in Figure 6, consists of fields of firn and ice and adjacent talus accumulations, and is representative of the other tributary accumulation zones.

The transition from the lower reaches of the accumulation zone to the rock glacier proper is roughly delineated by the absence of exposed firn and ice at the end of summer. Below the accumulation zone, the unconsolidated debris mantle fully blankets the ice-rock core. We infer that this mantle develops primarily by melting of the ice matrix during summer, leaving the debris on the surface. Once a sufficiently thick layer of debris has accumulated, it insulates the underlying ice, inhibiting further melting.

Ice growth in the rock-glacier system far removed from the accumulation zone must also be considered. A clean pod of ice was observed at the terminus in the furrow atop the contact of the west and middle tributaries. This ice was probably formed by freezing of the meltwater stream that was audible immediately upstream in the furrow.

The dominant process that nourishes the tributaries of the main stem is accumulation of polygenetic ice and talus at the base of the headwall. Deformation of the resulting ice and talus during flow is thought to be responsible for the composition and structure of the rock glacier at its terminus. 


\section{SUMMARY AND CONCLUSIONS}

In a study of the internal composition and structure revealed in a full transverse cross-section through the terminus of Fireweed rock glacier, we found that:

(1) The rock glacier is composed of a debris-covered icerock mélange, built by steady-state accumulation of polygenetic ice and talus at the bases of cirque headwalls and subsequently moved en masse by downslope flow.

(2) The ice matrix displays flow signatures such as elongate bubbles, foliation, large interlocking crystals, and folded strata.

(3) Prolate and tabular-shaped englacial clasts are preferentially aligned parallel to foliation and folded strata. Foliation and folded strata are generally oriented parallel to the steep bedrock channel walls containing the trunk stream.

(4) Convergence of the tributary rock glaciers, and down-valley narrowing of the gorge containing the trunk stream, impart a component of transverse compression to the flow, producing the steeply dipping, longitudinally striking structures.

\section{AGKNOWLEDGEMENTS}

Much appreciated for their companionship, hard work, and helpful discussions in the field are P. Churchill, A. Elconin, T. Finkle, M. Hunt, T. Kuklinski, M. MacDonald, J. Ogrodnik and C. Richards. We thank R. LeB. Hooke, W. Haeberli and an anonymous reviewer for their insightful comments on our findings and their suggestions for improving the manuscript.

\section{REFERENCES}

Allen, C. R., W. B. Kamb, M. F. Meier and R.P. Sharp. 1960. Structure of the lower Blue Glacier, Washington. f. Geol., 68 (6), 601-625.

Barsch, D. 1977. Ein Permafrostprofil aus Graubünden, Schweizer Alpen. Z Geomorphol., $21(1), 79-86$.

Barsch, D., H. Fierz and W. Haeberli. 1979. Shallow core drilling and borehole measurements in the permafrost of an active rock glacier near the Grubengletscher, Wallis, Swiss Alps. Arct. Alp. Res., 11 (2), 215-228.

Bateman, A. M. and D. H. McLaughlin. 1920. Geology of the ore deposit of Kennecott, Alaska. Econ. Geol., 15(1), 1-80.

Bates, R. L. and J. A. Jackson, eds. 1987. Glossary of geology. Third edition. Alexandria, VA, American Geological Institute.

Boulton, G. S. 1970. On the origin and transport of englacial debris in Svalbard glaciers. f. Glaciol., 9 (56), $213-229$.

Brown, W. H. 1925. A probable fossil glacier. 7. Geol., 33 4), 464-466.

Capps, S. R., Jr. 1910. Rock glaciers in Alaska. J. Geol., 18 (4), 359-375.

Echelmeyer, K. and Wang Zhongxiang. 1987. Direct observation of basal sliding and deformation of basal drift at sub-freezing temperatures. $\mathcal{F}$. Glaciol., 33 (113), 83-98.

Elconin, R. F. 1992. Amazon Gulch rock glacier complex: a summer study. (B.Sc. thesis, Humboldt State University, Arcata, CA.

Fisch, W., Sr, W. Fisch, Jr and W. Haeberli, 1978. Electrical D.C. resistivity soundings with long profiles on rock glaciers and moraines in the Alps of Switzerland. Z. Gletscherkd. Glazialgeol., 13(1-2), 1977, $239-260$.

Glen, J.W., J. J. Donner and R. G. West. 1957. On the mechanism by which stones in till become oriented. Am. J. Sci., 255 (3), 194-205.

Gomez, B. and R.J. Small. 1985. Medial moraines of the Haut Glacier d'Ar- olla, Valais, Switzerland: debris supply and implications for moraine formation. 7. Glaciol., 31 (109), 303-307.

Gunn, B. M. 1964. Flow rates and secondary structures of Fox and Franz Josef Glaciers, New Zealand. J. Glaciol., 5 (38), 173-190.

Hacberli, W. 1985. Creep of mountain permafrost: internal structure and flow of Alpine rock glaciers. Eidg. Tech. Hochschule, Zürich. Versuchsanst. Wasserbau, Hydrol. Glaziol. Mitt. 77.

Haeberli, W. and D. vonder Mühll. 1996. On the characteristics and possible origins of ice in rock glacier permafrost. Z. Geomorphol., 104, Supplementband, 43-57.

Haeberli, W., J. Huder, H.-R. Keusen, J. Pika and H. Röthlisberger. 1988. Core drilling through rock glacier-permafrost. In Senneset, K., ed. Permafrost. Fifth International Conference. Proceedings. August 2-5, 1988. Vol. 2. Trondheim, Tapir Publishers, 937-942.

Ham, N. R. and D. M. Mickelson. 1994. Basal till fabric and deposition at Burroughs Glacier, Glacier Bay, Alaska. Geol. Soc. Am. Bull., 106(12), $15.52-1559$.

Hambrey, M.J. 1975. The origin of foliation in glaciers: evidence from some Norwegian examples. f. Glaciol., $14(70), 181-185$.

Hambrey, M. J. 1976. Debris, bubble, and crystal fabric characteristics of foliated glacier ice, Charles Rabots Bre, Okstindan, Norway. Arct. Alp. Res., 8(1), 49-60.

Hambrey, M. J. 1977. Foliation, minor folds and strain in glacier ice. Tectonophysics, $39(1-3), 397-416$.

Hambrey, M.J. 1979. Correspondence. Origin of foliation in glaciers: comments on a paper by R. L. Hooke and P. J. Hudleston. f. Glaciol., 22 (88), $556-559$.

Hambrey, M. J. and F. Müller. 1978. Structures and ice deformation in the White Glacier, Axel Heiberg Island, Northwest Territories, Canada. J. Glaciol., 20 (82), 41-66.

Hamre, D. and D. McCarty. 1996. Jigback Tops Lone Peak. Ski Area Management, 35 (1), 72-73.

Holmes, C. D, 1941. Till fabric. Geol. Soc. Am. Bull., 52, 1299- 1354.

Hooke, R. LeB. and P.J. Hudleston. 1978. Origin of foliation in glaciers. J. Glaciol., 20 (83), 285-299.

Hooke, R. LeB. and P.J. Hudleston. 1980. Ice fabrics in a vertical flow plane, Barnes Ice Cap, Canada. J. Glaciol., 25 (92), 195-214.

Jeffery, G. B. 1922. The motion of ellipsoidal particles immersed in a viscous fluid. Proc. R. Soc. London, Ser. A, 102 (715), 161-179.

Johnson, J. P., Jr and W. G. Nickling. 1979. Englacial temperature and deformation of a rock glacier in the Kluane Range, Yukon Territory, Canada. Can. J. Earth Sci., 16 (12), $2275-2283$.

Lawson, D. E. 1979. A comparison of the pebble orientations in ice and deposits of the Matanuska Glacier, Alaska. J. Geol., 87 (6), 629-645.

McCall, J. G. 1952. The internal structure of a cirque glacier. Report on studies of the englacial movements and temperatures. F. Glaciol., 2(12), $122-131$.

Manley, R. St. J., A. P. Arlov and S. G. Mason. 1955. Rotations, orientations and collisions of suspended particles in velocity gradients. Nature, $175(4459), 682-683$.

Matthews, P. E., R. A. B. Bond and J. J. van den Berg. 1971. Analysis and structural implications of a kinematic model of similar folding. Tectonophysics, 12, 129-154.

Moore, D.W. and I. Friedman. 1991. Longitudinal section of an alpine rock glacier exposed south of Berthoud Pass, central Colorado Front Range. Geol. Soc. Am. Abstr. Programs, 23 (4), 50.

Potter, N., Jr. 1972. Ice-cored rock glacier, Galena Creek, northern Absaroka Mountains, Wyoming. Geol. Soc. Am. Bull., 83 (10), 3025-3057.

Reheis, M.J. 1975. Source, transportation and deposition of debris on Arapaho Glacier, Front Range, Colorado, U.S.A. J. Glaciol., 14 (72), 407-420.

Rogerson, R.J., M. E. Olson and D. Branson. 1986. Medial moraines and surface melt on glaciers of the Torngat Mountains, northern Labrador, Canada. 7. Glaciol., $32(112), 350-354$.

Rutter, N.W. 1965. Foliation pattern of Gulkana Glacier, Alaska Range, Alaska. J. Glaciol., 5 (41), 711-718.

Sharp, M. 1982. Modification of clasts in lodgement tills by glacial erosion. f. Glaciol., $28(100), 475-481$.

Wahrhaftig, C. and A. Cox. 1959. Rock glaciers in the Alaska Range. Geol. Soc. Am. Bull., 70 (4), 383-436.

Wayne, W. J. 1981. Ice segregation as an origin for lenses of non-glacial ice in "ice-cemented" rock glaciers. J. Glaciol., 27 (97), 506 -510. 